\title{
Newborn Hearing Screening Status in Korea
}

\author{
Su-Kyoung Park \\ Department of Otorhinolaryngology-Head and Neck Surgery, Kangnam Sacred Heart Hospital, Hallym University College of Medicine, Seoul, Korea
}

한국의 신생아청각선별검사 현황

박 수 경

한림대학교 의과대학 강남성심병원 이비인후과학교실

\begin{abstract}
South Korea has about 450 thousand neonates every year. Korea has very low birth rate and the fertility rate is the lowest in the world. Korean Ministry of Health and Welfare (KMHW) has been supported newborn hearing screening system since 2007. The aim of this study is to explain Korean NHS system and investigate the results of national NHS through 2009 to 2013 (5 years). In 2007 and 2008 , the 1st and 2nd area based national exhibition NHS projects were implemented. The 3rd national NHS project for low income babies has been conducted in all area from 2009 to now. From 2009, we adopted a coupon system to follow the screening babies. A free coupon is issued to pregnant women at the public health center. The babies born at the small women's clinic can visit any general hospital within 30 days for screening test. The referred babies from any listed screening clinics also can visit any hospital where confirming test is available within 90 days after birth. The collected coupons from each institute were sent to the Ministry of Health and Welfare to get reimbursement. By analyzing coupons, a tracking of baby will be possible. The Average hearing loss rate of total babies in this study was about 4.3 per 1,000 babies (> $40 \mathrm{~dB} \mathrm{HL}$ ) and average referral rate was 1.4\%. We have been tried for KMHW to support all newborn NHS and organized expert group for NHS, produced clinical guideline of NHS in 2010 and opened on-line education site for screener in 2013. Korean government supported only around $8.8 \%$ of the total newborns until 2013 year. We anticipate launching a nationwide mandatory UNHS program as soon as possible.
\end{abstract}

Key Words: Hearing loss, Neonatal screening, Transient evoked otoacoustic emissions, Auditory brainstem response.

Received: February 12, 2016 / Accepted: March 10, 2016

Correspondence: Su-Kyoung Park, Department of Otorhinolaryngology-Head and Neck Surgery, Kangnam Sacred Heart Hospital, Hallym University College of Medicine, 1 Singil-ro, Yeongdeungpo-gu, Seoul 07441, Korea

Tel: +82-2-829-5217 / Fax: +82-2-842-5217 / E-mail: ashock@daum.net

\section{INTRODUCTION}

양측 중등도 이상의 선천성 난청은 신생아 1,000 명당 $3 \sim 5$ 명 에서 발생하고, 고도 난청은 신생아 1,000명당 1 2명에서 발생 한다(Norton et al., 2000; Thompson et al., 2001; ASLHA, 2007; Yoshinaga-Itano \& Gravel, 2001; Yoshinaga-Itano et al., 1998) 청력을 결정하는 달팽이관은 엄마가 임신이라는 것 을 알게 될 무렵인 태생 6주 경부터 회전을 시작하여 태생 8주 말에 완성된다. 임신 중기에 달팽이관이 기능을 시작하면서 아 빠, 엄마의 목소리를 배속에서도 들을 수 있어 태교가 가능해 진다. 아기가 출생하면 달팽이관은 발달이 완성된 상태이나 언 어청각을 담당하는 뇌의 발달은 이루어지지 않은 상태이기 때 문에 소리 자극이 뇌에 전달됨에 따라 점차 청각피질이 발달하
고 청각신경 세포간의 시냅스가 발달하여 말과 언어를 익히는 속도와 양을 증가시킨다. 소리 자극에 의존한 대뇌 청각의 발달 은 대부분 생후 2 3년 내에 이루어지기 때문에 이 시기에 정상 청력으로 소리를 잘 듣는 것이 매우 중요하다. 난청이 있는 아 이가 신생아시기에 청각선별검사를 시행하지 않을 경우 일반적 으로 난청이 발견되는 시기는 생후 30 개월 전후로 이 시기에는 청각재활치료를 하여도 정상 아이들의 언어수준에 도달하기가 어렵다(Yoshinaga-Itano \& Gravel, 2001).

이에 선진국들은 생후 1 개월 이내 청각선별검사를 시행하고, 선별검사에서 어느 한쪽 귀라도 재검(refer) 판정을 받은 경우 생후 3 개월이내 난청 확진을 위한 정밀청력검사를 시행하고, 최종 난청을 진단 받은 경우 생후 6개월 이내 보청기 등의 청각 재활치료를 시행하도록 하는 "1-3-6 원칙"을 제시하고 있다 
(ASLHA, 2007; USPSTF, 2008).

국내의 신생아청각선별검사는 2000년대 초에 분만산부인과 를 중심으로 도입되었으며 2003년도부터는 대한청각학회 주도 로 청각선별검사 정착을 위해 매년 워크샵을 개최하고, 온라인 교육 연수교육 사이트 개발 등 다양한 활동을 시행하고 있다. 국내 신생아들은 매년 약 45 만명이 출생하고 있으며 국내 신생 아 출생률은 전세계 가장 낮은 출생률을 보이고 있다. 정부는 저출산을 극복하기 위한 국가정책의 일환으로 보건복지부에서 2007년부터 신생아 난청 조기진단사업을 시작하였다. 보건복지 부에서는 2007년과 2008년에 지역별 신생아난청 조기진단 시 범사업을 시행하였고, 2009년부터 현재까지 전국 저소득층을 대상으로 신생아 청각선별검사와 난청확진검사(1회의 청성뇌간 반응검사)를 지원하고 있으나 아직 전 신생아를 대상으로 시행 하고 있지는 않으며 또한 난청추적을 위한 질관리 시스템은 없 는 실정이다(The Korean Audiological Society, 2010).

본 연구의 목적은 보건복지부가 지원하는 국내 신생아청각 선별검사의 시스템을 설명하고 본 시스템에서 추적조사가 가능 하였던 2009년부터 2013년 결과를 분석해보고자 한다.

\section{MATERIALS AND METHODS}

본 연구의 대상자는 전국 저소득층의 신생아들로 쿠폰이 도 입된 2009년부터 2013년까지 대상자 202,137명을 대상으로 하 였다. 대상 신생아들이 보호자들은 출산 전 거주지 보건소에서 무료쿠폰을 발급받아 출산 후 입원기간 중 또는 생후 1개월 이 내 지정 선별검사병원(주로 분만산부인과)에서 쿠폰을 제출하 고 신생아청각선별검사를 시행 받았다. 신생아청각선별검사에
서 어느 한쪽 귀라도 재검(refer) 판정을 받은 경우 생후 3개월 이내 청성뇌간반응검사가 가능한 이비인후과에서 난청여부를 진단받도록 하였다. 확진검사를 시행한 보호자는 시행한 청성 뇌간반응 검사결과를 확진검사쿠폰에 기재 받고 해당 검사 영 수증을 거주지 보건소에 제출하여 검사비를 환불받았다. 선별 검사병원은 보건복지부에 선별검사 쿠폰을 제출하여 검사비를 청구하고(자동청성뇌간반응검사 27,000 원, 자동이음향방사검 사 10,000 원) 보건복지부와 보건소에 모인 쿠폰들을 취합하여 결과를 분석하였다(Figure 1).

\section{RESULTS}

2009년부터 2013년까지 5년동안 보건복지부 지원을 받아 신 생아청각선별검사를 시행한 신생아는 총 202,137 명이었다. 같 은 기간 동안 국내 출생한 총 신생아의 수가 2,307,435명이므로 전 신생아 대비 $8.8 \%$ 에서 국가의 지원을 받아 신생아난청 조기 진단검사를 시행하였다.

출생 후 청각선별검사를 시행한 검사일은 출생 후 평균 $5 \pm$ 8.3 일이었고, 재검 판정을 받은 신생아가 난청 여부를 진단받기 위해 시행한 정밀청력검사 시행일은 출생 후 평균 $64.0 \pm 47.1$ 일이었다. 청각선별검사에서 어느 한쪽 귀라도 재검 결과가 나오 는 비율인 재검률은 평균 $1.4 \%$ 이며 이를 시행한 의료기관별로 살펴보면 분만산부인과 $1.1 \%$, 종합병원 이비인후과 $7.2 \%$, 기타 개원의 $8.9 \%$ 였다. 시행한 선별검사 방법별 재검률은 자동청성뇌 간반응검사로 시행한 경우 $1.3 \%$, 자동이음향방사검사는 $2.4 \%$ 였다.

재검을 받은 신생아가 난청여부를 확진받기 위해 청성뇌간반
Figure 1. Flow diagram of government supported newborn hearing screening system in Korea. newborn hearing screening (NHS), automated auditory brainstem response (AABR), automated otoacoustic emissions (AOAE), ear, nose and throat department (ENT dept.), auditory brainstem response (ABR).

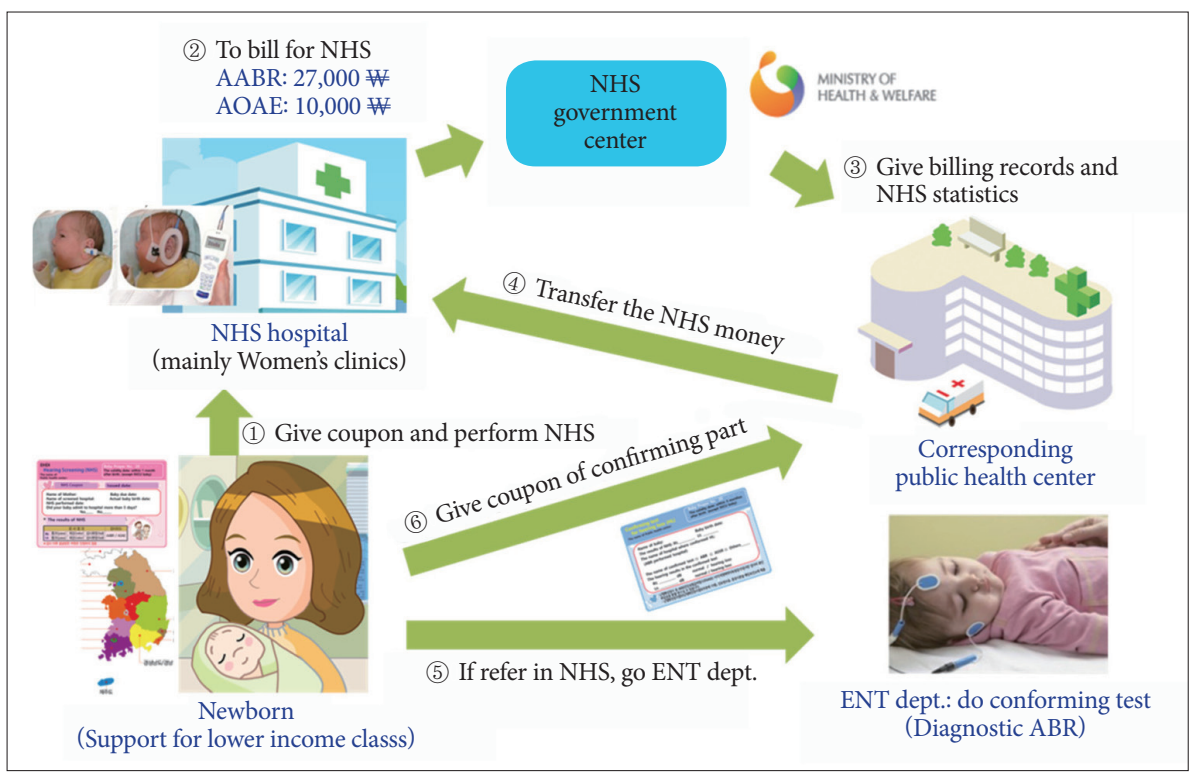


응검사를 시행한 비율인 확진검사율은 평균 $34.6 \%$ 로 2009년 43.4\%, 2010년 42.3\%, 2011년 32\% 2012년 28.3\%, 2013년 27.2\% 로 해마다 감소하였다. 난청발생률 $(40 \mathrm{~dB} \mathrm{HL}$ 기준)은 확진검 사율로 보정하였을 때 일측성 난청을 포함하여 평균 $0.426 \%$ 로 신생아 1,000 명당 약 4명에서 난청아가 발생하였다.

\section{DISCUSSIONS}

2009년부터 2013년까지 5년간 보건복지부에서 신생아난청 조기진단을 위해 지원한 신생아는 같은 기간에 출생한 전 신생 아의 $8.8 \%$ 로, 선진국의 경우 모든 신생아들을 국가적으로 의 무적으로 청각선별검사를 시행하도록 하는 정책과 비교해 보 았을 때 매우 낮은 수치이다. 재검률은 평균 $1.4 \%$ 로 특히 분만 산부인과에서의 재검률은 $1.1 \%$ 로 매우 낮아 위음성률의 가능 성이 있을 수 있음을 시사하였다.

5 년간 신생아 난청은 1,000 명당 약 4 명에서 발생함을 알 수 있었으나, 재검아들이 실제로 난청 여부를 확인하는 확진검사 율이 해마다 낮아지고 평균 $34.6 \%$ 를 보여 난청 발생률은 이보 다 더 높은 수치일 수 있으며, 선별검사를 시행하고도 난청 여 부를 최종 확인하지 않아 난청을 간과하고 청각장애가 될 수 있는 가능성이 있으므로 재검 판정을 받은 신생아들이 보다 편 리하게 확진검사비를 지원받아 검사를 시행할 수 있는 시스템 과 질관리가 필요하다.

보건복지부에서는 2018년부터는 건강보험 중기보장성 강화계 획의 일환으로 신생아청각선별검사에 대하여 건강보험 적용을 확대하고 뇌병변, 지적장애를 포함한 청각장애 등으로 인해 언 어습득이 어려운 아동을 대상으로 한 언어치료에 대해서도 건 강보험을 적용하겠다고 발표하였다(Ministry of Health and Welfare, 2015). 2018년에는 국내 출생하는 모든 신생아들이 정 부 지원 하에 신생아청각선별검사(universal newborn hearing screening, UNHS)를 시행하여 조기에 난청을 진단받고 조기 에 재활을 시행하여 청각장애를 극복하기를 기대한다. 그러나 제대로된 UNHS를 위해서는 선별검사기관과 확진검사기관, 검 사를 시행한 신생아, 영유아들을 추적 조사하고, 난청아들이 청 각장애를 극복하기 위해 관리할 수 있는 질관리 시스템이 체계 적으로 갖추는 데에도 국가적인 지원이 선행되어야 할 것이다.

중심 단어 : 난청·신생아선별검사·이음향방사·청성뇌간반응.

\section{Acknowledgments}

본 연구는 보건복지부 출산정책과의 지원을 받아 이루어졌습니다. 연구를 적극적으로 도와주신 보건복지부, 전국 보건소, 지정선별검 사기관, 대한청각학회께 진심으로 감사드립니다.

\section{REFERENCES}

American Speech-Language-Hearing Association. (2007). Year 2007 position statement: Principles and guidelines for early hearing detection and intervention programs. Pediatrics, 120(4), 898-921. doi:10.1542/ peds.2007-2333.

Ministry of Health and Welfare. (2015). 2014-2018 Mid-term health insurance plan protection-type reinforcement. Sejong, Korea: Ministry of Health and Welfare.

Norton, S. J., Gorga, M. P., Widen, J. E., Folsom, R. C., Sininger, Y., ConeWesson, B., et al. (2000). Identification of neonatal hearing impairment: a multicenter investigation. Ear and Hearing, 21(5), 348-356.

The Korean Audiological Society. (Ed.). (2010). Korean clinical practice guildline: Newborn hearing screening.

Thompson, D. C., McPhillips, H., Davis, R. L., Lieu, T. L., Homer, C. J., \& Helfand, M. (2001). Universal newborn hearing screening: summary of evidence. The Journal of the American Medical Association, 286(16), 2000-2010.

US Preventive Services Task Force. (2008). Universal screening for hearing loss in newborns: US Preventive Services Task Force recommendation statement. Pediatrics, 122(1), 143-148. doi:10.1542/peds.2007-2210.

Yoshinaga-Itano, C. \& Gravel, J. S. (2001). The evidence for universal newborn hearing screening. American Journal of Audiology, 10(2), 62-64.

Yoshinaga-Itano, C., Sedey, A. L., Coulter, D. K., \& Mehl, A. L. (1998). Language of early- and later-identified children with hearing loss. Pediatrics, 102(5), 1161-1171. 